\title{
Severe Systemic Rash in the Treatment of Hairy Cell Leukemia with Cladribine: Case Report and Literature Review
}

This article was published in the following Dove Press journal: International Journal of General Medicine

\author{
Huijie Dong ${ }^{1, *}$ \\ Yingying Shen ${ }^{1,2, *}$ \\ Yiping Shen ${ }^{1,2}$ \\ Dijiong Wu $\mathbb{D}^{1,2}$
}

'First Clinical College of Zhejiang Chinese Medical University, Hangzhou, Zhejiang 310053, People's Republic of China; ${ }^{2}$ Department of Hematology, First Affiliated Hospital of Zhejiang Chinese Medical University, Hangzhou, Zhejiang 310006, People's Republic of China

*These authors contributed equally to this work
Correspondence: Dijiong Wu Department of Hematology, First Affiliated Hospital of Zhejiang Chinese Medical University, 54 Youdian Road, Hangzhou, Zhejiang 310006, People's Republic of China

Email wudijiong@zcmu.edu.cn

\begin{abstract}
A 49-year-old male patient who had been diagnosed with variable hairy cell leukemia (HCL-V) was treated with interferon for half a year but exert no obvious effect. After two courses of chemotherapy with cladribine, he achieved remission, and splenomegaly significantly improved (the length in craniocaudal dimension decreased from $15.8 \mathrm{~cm}$ to $11.8 \mathrm{~cm}$ ). Four years later, the patient got disease relapse and was recommended for another cycle of cladribine ( $6 \mathrm{mg}$ for 7 days). On the last day of cladribine, the patient developed fever with needle-like red rashes on the face, limbs, and trunk. At the very beginning, the rash was lighter in color, sparsely distributed, and without obvious itching. Three days later, the rash gradually darkened, expanded and merged, with itching. With the application of high dose gamma globulin and corticosteroids (prednisolone combined with dexamethasone), the rash finally faded, and the patient was discharged. Rash caused by cladribine is not uncommon, such serious and widespread drug-induced rash is rare, and there are few reports. This article reviewed relevant studies and treatments.
\end{abstract}

Keywords: hairy cell leukemia, cladribine, system rash, side effect

\section{Introduction}

Hairy cell leukemia (HCL) is a rare B cell chronic lymphoproliferative disease (B-CLPD), with a characteristic of villous processes on the cell surface and "fried egglike" cytoplasm. It can be divided into classic hairy cell leukemia (HCL-C) and variable hairy cell leukemia (HCL-V). ${ }^{1}$ Flow immunotyping showed mature B cell-associated antigen expression and high expression of CD20 and CD22, ${ }^{2}$ CD 103 and Annexin A1 were specifically expressed in HCL. ${ }^{3,4}$ The current first-line treatment for HCL, whether HCL-C or HCL-V, is purine nucleoside analogs (PNA) cladribine, ${ }^{5}$ which has a high complete remission rate, but also with high unpredictable side effects, such as bone marrow suppression, infection, skin reactions, and secondary malignant tumors. Herein, we report a rare case of HCL-V that showed severe denudation-like systemic rash after cladribine treatment. To the best of our knowledge, only five cases have been reported, two with HCL and the other three with chronic lymphocytic leukemia (CLL). Our case will help better understanding the development and prognosis of the severe rash in HCL during cladribine application.

\section{Case Presentation}

A 49-year-old male without underlying diseases presented abdominal distension and fatigue in January 2015. He was diagnosed with HCL-V by bone marrow aspiration, 
immunophenotyping, and related gene tests (BRAF-V600E). Two cycles of Cladribine ( $7 \mathrm{mg}, \mathrm{d} 1-\mathrm{d} 5$ (day, d)) were administered on August 8 and September 23, 2016, respectively. The patient did not present fever, rash, or other side effects during the process. Moreover, the size of the spleen was significantly reduced after treatment (with a length in craniocaudal dimension from $15.8 \mathrm{~cm}$ to $11.8 \mathrm{~cm}$ ), and the case achieved disease remission.

Four years later (On July 9th, 2019), the patient complaining of fatigue and recurrence of abdominal distension, and admitted to our hospital. Blood routine test showed white blood cell (WBC) $2.6 \times 10^{9} / \mathrm{L}$, lymphocyte $41.7 \%$, hemoglobin $(\mathrm{Hb}) 132 \mathrm{~g} / \mathrm{L}$, and platelet (PLT) $88 \times 10^{9} / \mathrm{L}$. Lymphocyte subsets with flow cytometry showed $54.63 \%$ T cell (CD3+CD45), 31.06\% B cell (CD19+) and 10.4\% Treg (CD4+/CD25+/CD127-). Ultrasound indicated splenomegaly (with a length of $13.8 \mathrm{~cm}$ in craniocaudal dimension), and lymphadenopathy in bilateral neck, supraclavicular, and inguinal. Bone marrow aspiration showed that lymphocytes accounted for $12.5 \%$, and no obvious abnormality was detected in morphology. Flow immunophenotyping can detect abnormal B lymphocyte population, the phenotype was similar to the initial course and mainly expressed CD19++, CD45++, HLA-DR++, CD22++, CD20++,
CD103++, CD99+, CD25-, CD117-, CD56-, and FMC7-

(Figure 1), which indicated the relapse of the disease.

Four days later, the patient was initiated with cladribine at the dosage of $6 \mathrm{mg}$, from day (d) 1 to $\mathrm{d} 7$. On the last day of treatment, the patient developed a slight skin rash with itching on the chest, for which, anti-allergic drugs were administered. However, he had a high fever (over $39^{\circ} \mathrm{C}$ ) and shivering with rash spreading throughout the body in the afternoon. The detection of $\mathrm{C}$ reaction protein (CRP) and procalcitonin (PCT) showed slight increase (CRP 30mg/L and PCT $0.35 \mathrm{ng} / \mathrm{mL}$ ), and Chest CT did not indicate any infection. On the next day, the rash still worsened without oral mucosa and genitalia involvement. The relative of the patient complained about the situation and reject to perform the skin biopsy. Considering the continued fever, the possibility of secondary infection could not be fully excluded. Moxalactam was further administered for anti-infection, and dexamethasone $5 \mathrm{mg} \times 7 \mathrm{~d}$ combined with methylprednisolone $40 \mathrm{mg} \times 10$ $\mathrm{d}$ for anti-inflammatory. During the first two days of treatment, the patient still had a high fever with a systemic rash. Moreover, the rash on the chest and abdomen, back, and both lower limbs (Figure 2A-C) darkened and was intensively distributed. Ascribe to the hematological
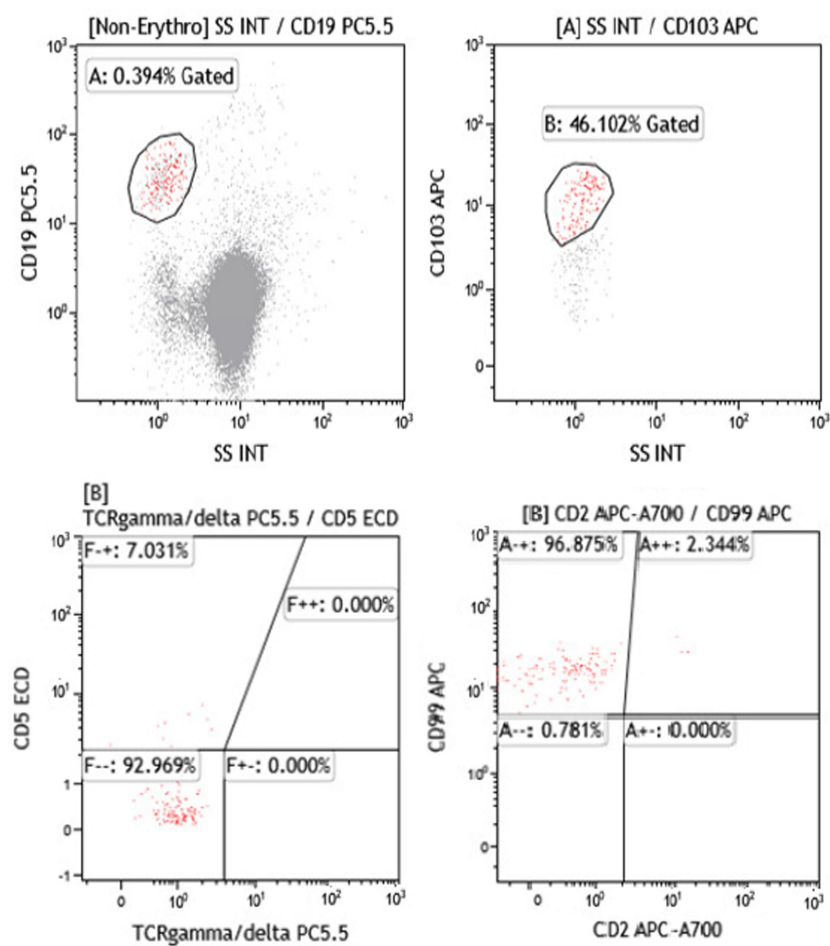
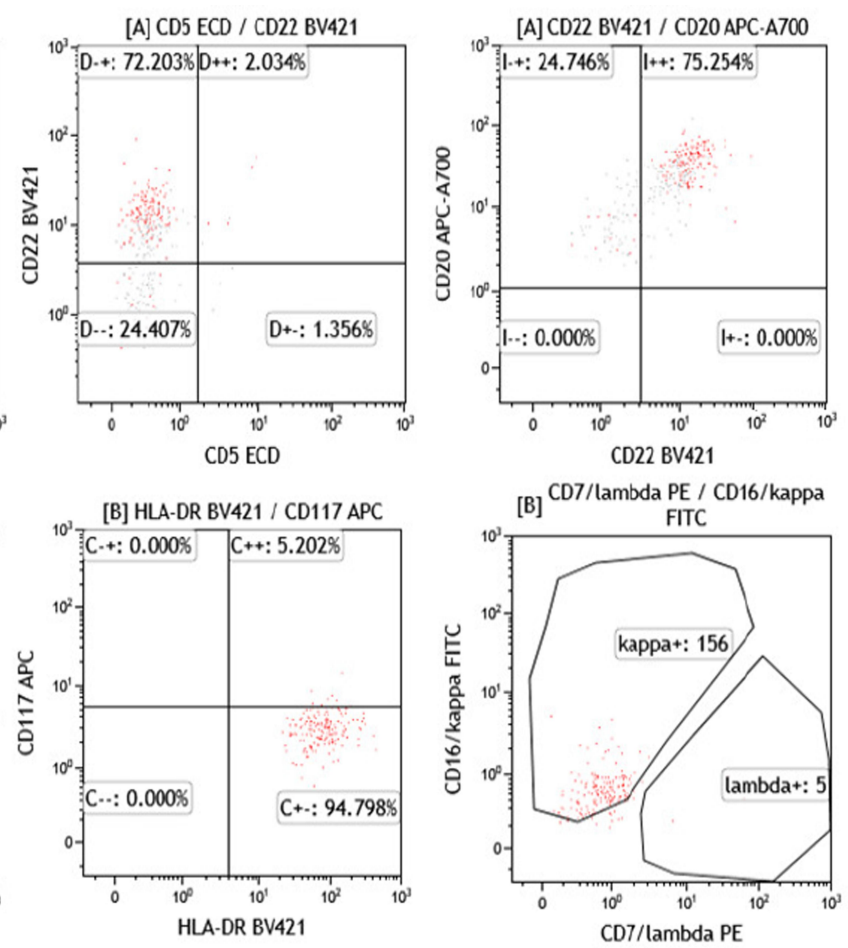

Figure I Flow cytometric (FCM) immunophenotyping of the bone marrow. FCM indicated that the abnormal B lymphocyte population mainly expressed CDI9, CD45, HLA-DR, CD22, CD20, CDI03, CD99 and negative for CD25, CDII7, CD56, and FMC7. 

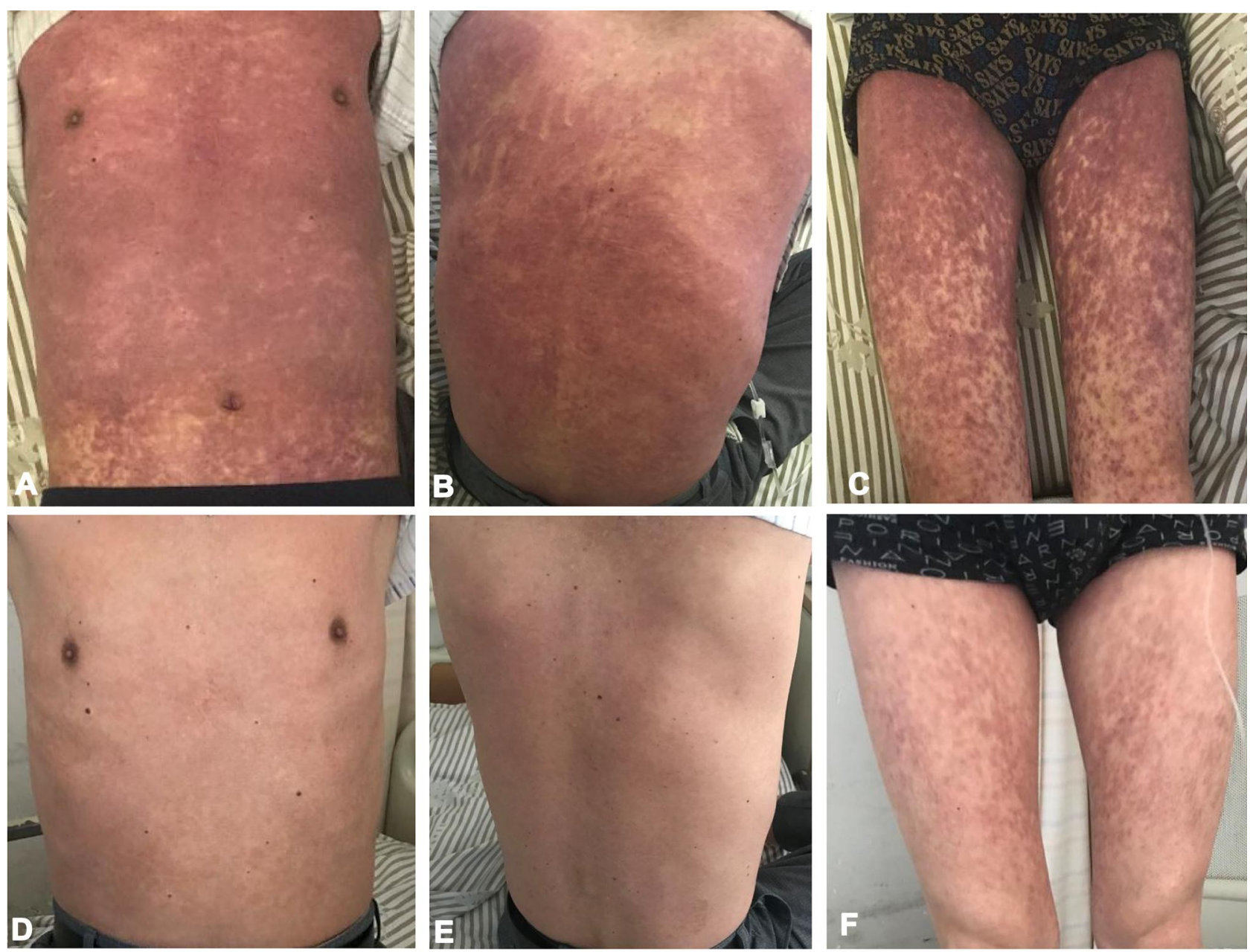

Figure 2 The change of skin rash induced by cladribine in $\mathrm{HCL}$, before (A-C) and after (D-F) rescue. The diffuse, exfoliated, and itchy erythema (throughout the chest, back and limbs) gradually faded after a combination treatment with corticosteroids, immunoglobulin, ebastine, and sodium thiosulfate.

toxicity of cladribine, the patient suffered from neutrophil deficiency, granulocyte colony-stimulating factor (G-CSF) was used to stimulate the hematopoiesis and the antibiotic was changed to Meropenem. Three days later, the patient's body temperature returned to normal, but no significant decrease was observed in the systemic rash. Immunoglobulin $15 \mathrm{~g} /$ day was added for 3 days to alleviate the immune response, ebastine was taken orally, and sodium thiosulfate was administered for anti-allergic treatment. Five days more, the rash began to fade, and disappeared 10 days later. Then, the patient was discharged (Figure 2D-F).

\section{Discussion}

HCL accounts for $2 \%$ of adult leukemia, the median age of onset was $60-70$ years. ${ }^{6}$ Purine analogs are currently the standard first-line treatment for any type of HCL. Cladribine and pentostatin alone can achieve a high complete remission (CR) rate, but $\mathrm{HCL}$ is prone to relapse. ${ }^{7}$ Rosenberg et $\mathrm{al}^{8}$ reported the first-line treatment of cladribine in 88 young patients with HCL, among whom, the longest median overall survival (OS) was 231 months. Adverse reactions of cladribine including bone marrow suppression (neutropenia, thrombocytopenia and anemia), infection (bacteria, virus, fungus, and herpes simplex), skin reactions (rash, papules, and erythema with the incidence rate $21-51 \%)$, ${ }^{2,9}$ secondary malignant tumors, autoimmunity disorder, and rare toxicity. ${ }^{10,11}$ Among which, bone marrow suppression and infection are most common. The presentation of skin reactions was not rare during cladribine treatment, but most of them were mild rashes. Currently, limited data are available (3 papers with 5 cases) on extremely severe skin rash caused by cladribine (Table 1). In our case, the patient developed a severe systematic skin rash (except oral cavity and genitalia) on the last cladribine injection, which presented 
Table I Comparison of the Literature on Cases of Severe Rash During the Cladribine Treatment in HCL and CLL

\begin{tabular}{|c|c|c|c|c|c|c|c|c|}
\hline Case & Study & $\begin{array}{l}\text { Age } \\
\text { (Years)/ } \\
\text { Gender }\end{array}$ & $\begin{array}{l}\text { Primary } \\
\text { Disease }\end{array}$ & Treatment & $\begin{array}{l}\text { Skin Rash } \\
\text { (Manifestation) }\end{array}$ & Fate & $\begin{array}{l}\text { Skin Rash } \\
\text { Treatment }\end{array}$ & $\begin{array}{l}\text { Suspicious } \\
\text { Combined Drugs }\end{array}$ \\
\hline I & $\begin{array}{l}\text { Grey et al, }{ }^{14} \\
2000\end{array}$ & $82 / F$ & $\mathrm{HCL}$ & Cladribine & $\begin{array}{l}\text { Back, groin, then } \\
\text { quickly wide, blisters } \\
\text { (merged DIC) }\end{array}$ & Survive & Corticosteroids & $\begin{array}{l}\text { Allopurinol, } \\
\text { Imipenem, } \\
\text { Trimethoprim- } \\
\text { sulfamethoxazole }\end{array}$ \\
\hline 2 & $\begin{array}{l}\text { Grey et al, }{ }^{14} \\
2000\end{array}$ & $67 / F$ & $\mathrm{HCL}$ & Cladribine & $\begin{array}{l}\text { Back to body } \\
\text { erythema }\end{array}$ & Survive & Corticosteroids & $\begin{array}{l}\text { Trimethoprim- } \\
\text { sulfamethoxazole, } \\
\text { Imipenem }\end{array}$ \\
\hline 3 & $\begin{array}{l}\text { Meunier } \\
\text { et al, }{ }^{17} \text { I996 }\end{array}$ & $N / F$ & $\mathrm{HCL}$ & Cladribine & $\begin{array}{l}\text { Toxic epidermal } \\
\text { necrolysis }\end{array}$ & Survive & Unknown & $\begin{array}{l}\text { Amoxicillin or } \\
\text { sulfonamides }\end{array}$ \\
\hline 4 & $\begin{array}{l}\text { Rossini et al, }{ }^{19} \\
2004\end{array}$ & $67 / M$ & CLL & $\begin{array}{l}\text { Chlorambucil, } \\
\text { Prednisone, } \\
\text { Cladribine }\end{array}$ & $\begin{array}{l}\text { Whole body itching, } \\
\text { rash (erythema, } \\
\text { blisters) }\end{array}$ & Survive & Corticosteroids & $\begin{array}{l}\text { Ciprofloxacin and } \\
\text { fluconazole as } \\
\text { prophylaxis }\end{array}$ \\
\hline 5 & $\begin{array}{l}\text { Rossini et al, }{ }^{19} \\
2004\end{array}$ & $62 / M$ & CLL & $\begin{array}{l}\text { Chlorambucil, } \\
\text { COP, } \\
\text { Cladribine }\end{array}$ & $\begin{array}{l}\text { Erythema, blisters, } \\
\text { ulcers, diffuse dermal } \\
\text { necrosis }\end{array}$ & Survive & Corticosteroids & $\begin{array}{l}\text { Ciprofloxacin and } \\
\text { fluconazole as } \\
\text { prophylaxis }\end{array}$ \\
\hline
\end{tabular}

Abbreviations: COP, cyclophosphamide, vincristine and prednisone; HCL, hairy cell leukemia; CLL, chronic lymphocytic leukemia; DIC, disseminated intravascular coagulation.

with high fever, diffuse, exfoliated, and itchy erythema throughout the body (face, limbs and trunk). With a timely multiple treatment for 10 days, including corticosteroids and immunoglobulin, the fever and rash got completely controlled and the occurrence of severe complication such as exfoliative dermatitis was avoided.

The underling mechanism of severe rash after cladribine application is not clear. Some studies considering that a large part of the skin reaction is associated with allopurinol. When cladribine and allopurinol are used together, it will increase the chance of rash, and the skin reactions alleviated spontaneously after allopurinol withdrawal. ${ }^{12,13}$ Two patients with HCL who received cladribine treatment in the same center had severe skin reactions; ${ }^{14}$ one received a combination of allopurinol and compound sulfamethoxazole, and on day 5 after treatment, the patient developed a severe rash with life-threatening bleeding and disseminated intravascular coagulation (DIC). Thus, the allopurinol and compound sulfamethoxazole were ceased, and hydrocortisone $200 \mathrm{mg} / 4 \mathrm{~h}$ was administered. The rash disappeared gradually after 1 week. ${ }^{15}$ Typically, allopurinol is used to treat hyperuricemia and tumor lysis, ${ }^{13}$ and patients using cladribine for HCL should avoid it as much as possible, so as in our case. In addition, some studies reported that the skin reaction after cladribine treatment might be correlated to increased drug hypersensitivity caused by cladribine-induced $\mathrm{T}$ cell imbalance. Ganzel et $\mathrm{al}^{9}$ collected $35 \mathrm{HCL}$ patients treated with cladribine, and found that the frequency of rashes was quite high (18/ $35,51 \%$ ), which could be attributed to the simultaneous use of penicillin/trimethoprim-sulfamethoxazole (TMPSMZ), G-CSF, and sulfonamides. ${ }^{16}$ Meunier reported that $21 \%(7 / 33)$ had skin reactions within one month after cladribine, and 5 might be related to the use of antibiotics. ${ }^{17}$ Also, in CLL patients treated with cladribine, the occurrence of skin lesions might be attributed to the simultaneous use of ciprofloxacin and fluconazole. ${ }^{18,19} \mathrm{In}$ our case, we consider that the onset of body rash may ascribe to the accumulation of cladribine, and the early prophylactic anti-infection may contribute to the delayed allergy. Simultaneously, to mitigate bone marrow suppression, G-CSF was utilized to promote the hematopoiesis. The use of antibiotics and G-CSF might accelerate the induction or aggravate the occurrence of severe rash.

The incidence of rash in non-leukemia disease, such as multiple sclerosis, is quite low $(\sim 2.4 \%)^{20}$ when compared with leukemia patient treated with cladribine. This reminds us that the primary disease may also be related to skin reactions. For severe and life-threatening skin reactions, we should intervene early to prevent the occurrence of toxic 
necrosis and dissolution. Desensitization schemes should be considered when simultaneous use with antibiotics, and the use of antibiotics and G-CSF should also be in caution when it is not determined whether the infection is bacterial or bone marrow suppression appeared agranulocytosis.

\section{Abbreviations}

HCL, hairy cell leukemia; CLPD, chronic lymphoproliferative disease; PNA, purine nucleoside analogs; CLL, chronic lymphocytic leukemia; WBC, white blood cell; $\mathrm{Hb}$, hemoglobin; PLT, platelet; CRP, C reaction protein; PCT, procalcitonin; G-CSF, granulocyte colonystimulating factor; $\mathrm{CR}$, complete remission; OS, overall survival; DIC, disseminated intravascular coagulation; TMP-SMZ, trimethoprim-sulfamethoxazole.

\section{Ethics Statment}

This study was approved by the ethical committee of the Zhejiang Provincial Hospital of TCM. Written informed consent was obtained from the individual for the publication of any potentially identifiable images or data included in this article.

\section{Author Contributions}

All authors made substantial contributions to conception and design, acquisition of data, or analysis and interpretation of data; took part in drafting the article or revising it critically for important intellectual content; agreed to submit to the current journal; gave final approval of the version to be published; and agree to be accountable for all aspects of the work.

\section{Funding}

The present study was supported by National Natural Science Foundation of China (NO. 81503296), Natural Science Foundation of Zhejiang Province (NO. LY21H290003, LY14H290001, Y2101416), Zhejiang Outstanding Young Talent Fund of Traditional Chinese Medicine (NO.2013ZQ012).

\section{Disclosure}

The authors report no conflicts of interest for this work.

\section{References}

1. Robak T. Management of hairy cell leukemia variant. Leuk Lymphoma. 2011;52(Suppl 2):53-56. doi:10.3109/10428194.2011.566392

2. Tiacci E, Pettirossi V, Schiavoni G, Falini B. Genomics of hairy cell leukemia. J Clin Oncol. 2017;35(9):1002-1010. doi:10.1200/ JCO.2016.71.1556
3. Wang HY, Zu Y. Diagnostic algorithm of common mature B-cell lymphomas by immunohistochemistry. Arch Pathol Lab Med. 2017;141(9):1236-1246. doi:10.5858/arpa.2016-0521-RA

4. Dong HY, Weisberger J, Liu Z, Tugulea S. Immunophenotypic analysis of CD103+ B-lymphoproliferative disorders: hairy cell leukemia and its mimics. Am J Clin Pathol. 2009;131(4):586-595. doi:10.1309/AJCPL13YDUHFKPJU

5. Benz R, Arn K, Andres M, et al. Prospective long-term follow-up after first-line subcutaneous cladribine in hairy cell leukemia: a SAKK trial. Blood Adv. 2020;4(15):3699-3707. doi:10.1182/ bloodadvances.2020002160

6. Grever MR, Abdel-Wahab O, Andritsos LA, et al. Consensus guidelines for the diagnosis and management of patients with classic hairy cell leukemia. Blood. 2017;129(5):553-560. doi:10.1182/blood-2016-01689422

7. Bibi A, Java S, Chaudhary S, et al. BRAFV600E mutation in hairy cell leukemia: a single-center experience. Indian J Pathol Microbiol. 2018;61(4):532-536.

8. Rosenberg JD, Burian C, Waalen J, Saven A. Clinical characteristics and long-term outcome of young hairy cell leukemia patients treated with cladribine: a single-institution series. Blood. 2014;123 (2):177-183. doi:10.1182/blood-2013-06-508754

9. Ganzel C, Gatt ME, Maly A, Ben-Yehuda D, Goldschmidt N. High incidence of skin rash in patients with hairy cell leukemia treated with cladribine. Leuk Lymphoma. 2012;53(6):1169-1173. doi:10.3109/10428194.2011.635864

10. Sigal DS, Miller HJ, Schram ED, Saven A. Beyond hairy cell: the activity of cladribine in other hematologic malignancies. Blood. 2010;116(16):2884-2896. doi:10.1182/blood-2010-02-246140

11. Wang TY, Li ZJ, Lyu R, et al. [Clinical analysis of 24 patients of hairy cell leukemia treated by cladribine]. Zhonghua Xue Ye Xue Za Zhi. 2018;39(6):491-495.

12. Chubar Y, Bennett M. Cutaneous reactions in hairy cell leukaemia treated with 2-chlorodeoxyadenosine and allopurinol. $\mathrm{Br}$ $J$ Haematol. 2003;122(5):768-770. doi:10.1046/j.13652141.2003.04506.x

13. Espinosa Lara P, Quiros Redondo V, Aguado Lobo M, JimenezReyes J. Purpuric exanthema in a patient with hairy cell leukemia treated with cladribine and allopurinol. Ann Hematol. 2017;96 (7):1209-1210. doi:10.1007/s00277-017-2992-z

14. Grey MR, Flanagan NG, Kelsey PR. Severe skin rash in two consecutive patients treated with 2-chlorodeoxyadenosine for hairy cell leukaemia at a single institution. Clin Lab Haematol. 2000;22 (2):111-113. doi:10.1046/j.1365-2257.2000.00283.x

15. Kreitman RJ. Hairy cell leukemia: present and future directions. Leuk Lymphoma. ～2019;60(12):2869-2879. doi:10.1080/10428194.2019. 1608536

16. Johnston JB, Glazer RI, Pugh L, Israels LG. The treatment of hairycell leukaemia with 2'-deoxycoformycin. Br J Haematol. 1986;63 (3):525-534. doi:10.1111/j.1365-2141.1986.tb07530.x

17. Meunier P, Castaigne S, Bastie JN, Chosidow O, Aractingi S. Cutaneous reactions after treatment with 2-chlorodeoxyadenosine. Acta Derm Venereol. 1996;76(5):385-386.

18. Robak T, Sysa-Jedrzejowska A, Robak E, Dabkowski J, BlasinskaMorawiec M. 2-chlorodeoxyadenosine (cladribine) induced allergic cutaneous reactions with eosinophilia in a patient with B-cell chronic lymphocytic leukemia. J Med. 1997;28(3-4):199-209.

19. Rossini MS, de Souza EM, Cintra ML, Pagnano KB, Chiari AC, Lorand-Metze I. Cutaneous adverse reaction to 2-chlorodeoxyadenosine with histological flame figures in patients with chronic lymphocytic leukaemia. J Eur Acad Dermatol Venereol. 2004;18(5):538-542. doi:10.1111/j.1468-3083.2004.00969.x

20. Cook S, Vermersch P, Comi G, et al. Safety and tolerability of cladribine tablets in multiple sclerosis: the CLARITY (CLAdRIbine Tablets treating multiple sclerosis orallY) study. Mult Scler. 2011;17 (5):578-593. doi:10.1177/1352458510391344 


\section{Publish your work in this journal}

The International Journal of General Medicine is an international, peer-reviewed open-access journal that focuses on general and internal medicine, pathogenesis, epidemiology, diagnosis, monitoring and treatment protocols. The journal is characterized by the rapid reporting of reviews, original research and clinical studies across all disease areas. The manuscript management system is completely online and includes a very quick and fair peer-review system, which is all easy to use. Visit http://www.dovepress.com/ testimonials.php to read real quotes from published authors. 